\title{
Phytochemical Analysis of Some Selected Plants and Families in the University Botanic Garden Of Maseno, Kenya.
}

\author{
*Stephen F. Sikolia ${ }^{1}$, Seline Omondi ${ }^{2}$ \\ Department of Botany, Maseno University, Kenya \\ Department of Botany, Maseno University, Kenya \\ Corresponding Author: Stephen F. Sikolia ${ }^{l}$
}

\begin{abstract}
There has scarcely been any attempt to carry out phytochemical analysis on various insitu and ex situ plants conserved at the University Botanic Garden and no research has been done to document the educational and economic values of the garden. Moreover, the rate at which the plant biodiversity is being cleared is alarming, and calls for urgent need of conserving plants of high economic values. It is on the basis of such need that the study was carried out at the University Botanic Garden, Maseno (UBGM). The study was carried out over a period of eleven months. The main objective of the study was to identify and provide checklist of plants conserved at the University Botanic Garden, Maseno. Phytochemical screening of five medicinal plant extracts in each of the ten selected plant families was done using various reagents and it revealed that saponins were the most abundant phytochemicals constituting $32.43 \%$, followed by alkaloids $(27.03 \%)$ then flavonoids (14.86 \%), steroids $(12.16 \%)$, terpenes $(10.81 \%)$ and anthraquinones $(2.70 \%)$ respectively. The data collected was presented using tables. Chi-square analysis at $P \leq 0.05$ reveals that plant families in which the plants are grouped are dependent on the phytochemicals present in plants. Therefore, there is relationship between the phytochemical obtained from plant and family classification of the plant in question. The information collected through annotated checklist will be used to provide database of vascular plants of high economic value found within the University Botanic Garden, provide information on phytochemicals present in some medicinal plants and hence need for sustainable biodiversity conservation. The knowledge of such medicinal plants will provide vital information to the local community members who still rely on herbal medicine for the treatment of most diseases.
\end{abstract}

Keywords: University Botanic Garden of Maseno, Flavonoids, Terpenes, Alkaloids, Steroids and anthraquinones, Medicinal Plants)

\section{Introduction}

Plants are vital for the survival and wellbeing of other organisms. However, the survival of most plants is threatened. According to BGCI (2011a) [1], and Rinker (2002) [2], it is estimated that there are 270,000 plant species in the world, one in eight are threatened with extinction. Humans are the main cause of extinction and the principle threat to species at risk of extinction [1]. The major threats to plant diversity include, habitat loss and degradation, invasive species, over-exploitation, pollution, disease and climate change (Jeruto, 2008 [3]; [1]; Oldfield, 2011 [4]). According to BGCI (2011b) [5], a quarter of the 1157 species of Rhododendron plants and 78 wild oaks are in danger of extinction. This therefore calls for need of their protection through ex situ conservation. Some of the plants at the University Botanic Garden, Maseno have medicinal values. For many centuries plant based medicaments have been man's prime weapon and still is in the frontline for treating large number of diseases [3]. In Kenya, the role of plants as sources of medicine has been recognized and as scientific knowledge on the medicinal values of indigenous plants increases (Rukangira, 2001) [6]there is a proportional increase in demand for herbal products both locally and internationally. In Traditional African societies, several medicinal plants were used to treat various diseases and conditions, for example, Prunus africanus bark (Pygeanum powder) has been used to treat prostate cancer, Rauvolfia species roots (reserpine) have been used to treat high blood pressure and Cinchona species whose active ingredient is quinine is used in the treatment of malaria (Swaminathan and Kochhar, 1989 [7]; Nyunja, Onyango and Beck, 2009 [8]). Expanding herbal product market poses a risk of over harvesting of medicinal plants and this has serious implications on the survival of several plant species, and threatens biodiversity. Further the local application and usage of the herbal medicine in the management of diseases and health care practices is on the increase in East Africa. This can be evidently seen in the number herbal clinics increase in the society. Also, herbal practitioners are also gaining credence in the public domain and positive perception. This therefore calls for conservation of medicinal plants of high economic values in the botanic garden. 
The plant kingdom represents an enormous reservoir of biologically active compounds (Shakeri,Hazeri, Vlizadeh, Ghasemi and Tavallaei,2012[9]). These biologically active compounds are called phytochemicals. Phytochemicals are basically divided into two groups, i.e. primary and secondary constituents, according to their functions in plant metabolism. Primary constituents comprise common sugars, amino acid, proteins and chlorophyll while secondary constituents consists of alkaloids, terpenoids, saponins, phenolic compounds, flavonoids, tannins and so on (Nonita and Mylene,2010[10];Ekeannyanwu, 2011[11]; Rahul, 2013[12]). The most important of these bioactive constituents of plants are alkaloids, tannins, flavonoids and phenolic compounds. Many of these have been studied and are still being studied under phytochemistry or natural product Chemistry (Nyunja, 2007)[14]. World plant biodiversity is the largest source of herbal medicine and it is now clear that, the medicinal value of these plants lies in the bioactive phytochemical constituents that produce definite physiological effects on human body (Nonita and Mylene, 2010). Research on phytochemistry needs to be intensified, and any attempt to obtain bioactive agents from plants is worthwhile (Eldin and Dunford, 1999)[15].Chemotaxonomy is the classification of organisms on the basis of the nature, content, and/or the distribution of constituent chemical substances (Cammack, Teresa, Campbell, Howard, Smith, Stirling and Vella, 2006)[16]. In Kenya, few indigenous plants have been screened for their pharmaceutical potential despite their richness in chemicals for pharmaceutical industries (Mutta, 1994) [17]. However, preliminary chemotaxonomic studies have been done on some Kenyan plants for instance, Githinji (1990) [18] carried out chemotaxonomic studies on selected Lamiaceae species and he analyzed 37 medicinal plants. Omino (1990) [19]carried out phytochemical tests to detect presence or absence of compounds in 6 Apocynaceae species, and established that, alkaloids and cardiac glycosides were the most abundant followed triterpenes and saponins while anthraquinones were generally absent. There have scarcely been any attempts to carry out phytochemical analysis on various in situ and ex situ plants conserved at the University Botanic Garden to find out the bioactive components present in them and no research has been done to document the educational and economic values of the garden. Moreover, currently in the neighbouring areas around the garden, just like in other several parts of the country, the survival of most plants in their natural setting is threatened as there is a lot of pressure on the plants due to land clearance to provide space for buildings, allied infrastructure development, agriculture and tree burning for charcoal. This therefore calls for conservation strategies to be put in place to save these plants from extinction. The aim of the study was to analyze phytochemical constituents of 5 selected medicinal plants in each of the ten families for chemotaxonomic values.In this study, phytochemical screening has been carried out on 50 plants, 5 each from the 10 selected plant families found in the UBGM. The distribution of the constituent secondary chemical compounds found in the members of each plant family has been used to show whether these compounds can sufficiently be used to group these plants in their families or not. Time coupled with financial implications has not allowed for quantity of each of the compound to be analyzed within and across various plant families, as this could have further emphasized the chemotaxonomic significance of these compounds in various plant families.

\subsection{Study area}

\section{Materials And Methods}

The University Botanic Garden, Maseno is located in Kisumu County. The garden is found within Maseno University. The UBGM was established in 2001 as a biodiversity centre for the Lake Victoria region (Onyango and Onyango, 2005) [19]. The garden lies at a latitude of $0^{\circ} 00^{\prime} 16.09^{\prime \prime}$ and longitude of $34^{\circ} 36^{\prime}$ 08.52 "at altitude of $1500 \mathrm{~m}$. Maseno area receives annual rainfall of about $1346 \mathrm{~mm}$ per year and the average temperature around the garden is $21.2^{\circ} \mathrm{C}$ with $20^{\circ} \mathrm{C}$ minimum and $23^{\circ} \mathrm{C}$ maximum daily temperatures (rice weather station in the garden). Garden size is about 7.0 hectares.

\subsection{Collection and Identification of the Plant species}

The identification of the plants in the garden was done through the use of taxonomic keys (Noad and Birnie, 1992[21]; Agnew and Agnew, 1994[22]; Olembo, Fedha and Ngaira, 1995 [23]) and by oral interviewing of ten University botanic garden staff about their knowledge of plant names and usage (Kokwaro, 1972[24]; Kokwaro, 1994[25]). Where the identity of the plant was not established, samples for plant specimen in question were collected using secateurs. These were taken to the Maseno University botany laboratory where they were placed inside a folded newspaper then pressed flat by placing within a sandwich of blotter papers and then tied in a plant press and put in a plant drier, where they were dried under standard conditions according to Stace (1993)[26]. They were then presented for identification at the University of Nairobi herbarium and confirmed at the East African Herbarium, Nairobi, Kenya.

\subsection{Preparation of samples for phytochemical analysis}

Leaves of plants from families that recorded high number of member frequencies were collected in labelled polythene bags. A total of 50 plants, 5 each from 10 plant families were collected from the botanic garden and transported to the laboratory. These included: Asteraceae, Fabaceae, Lamiaceae, Poaceae, 
Malvaceae, Apocynaceae, Acanthaceae, Araceae, Rutaceae and Solanaceae. They were then air dried for 2-3 weeks, and then ground into powder form using a blender mill. Each ground leaf sample was extracted using ethanol. The solvent was removed by distillation under reduced pressure and the resulting semisolid mass, thick syrup of about 12-15 $\mathrm{g}$ from $50 \mathrm{~g}$ of extracted dry powder was vacuum dried using flash evaporator. This extract was used for carrying out tests to determine presence or absence of secondary metabolites. The secondary metabolites tested were alkaloids, anthraquinones, flavonoids, steroids, terpenes and saponins. The standard phytochemical bioactive component identifications were carried out according to the following methods.

\subsubsection{Test for alkaloids}

According to a method of George, Ikot and Obi-Egbedi(2010)[27], $5 \mathrm{~mL}$ of $1 \%$ aqueous hydrochloric was added to $5 \mathrm{~g}$ of the extract and warmed in a water bath while stirring. It was then filtered and the filtrate was used to test for alkaloid as follows; $1 \mathrm{~mL}$ of the filtrate was treated with a few drops of Mayer's reagent. Creamy turbid dispersion indicated the presence of alkaloid. This observation was further confirmed by carrying out another alkaloid test thus; $1 \mathrm{ml}$ of the filtrate was treated with a few drops of Wagner's reagent. Reddish brown precipitate indicated the presence of alkaloid.

\subsubsection{Test for anthraquinones}

According to a method of George, Ikot and Obi-Egbedi(2010), $2.5 \mathrm{~g}$ of extract was boiled with $5 \mathrm{~mL}$ of $10 \%$ $\mathrm{H}_{2} \mathrm{SO}_{4}$ and filtered. The filtrate was shaken with $2.5 \mathrm{~mL}$ benzene. The benzene layer was separated, and $10 \%$ $\mathrm{NH}_{4} \mathrm{OH}$ added. A rose pink colouration in ammonia phase (lower phase) indicated the presence of anthraquinones.

\subsubsection{Test for flavonoids}

According to a method of Kumar and Gali (2011)[28], few drops of mercury hydroxide solution was added to $5 \mathrm{ml}$ of test solution. Intense yellow color was formed which turned to colorless on addition of few drops of dilute hydrochloric acid. This indicated the presence of flavonoids.

\subsubsection{Test for steroids and terpenes}

According to a method of [28], few drops of acetic anhydride was added to the $0.5 \mathrm{~g}$ of extract then boiled and cooled. Concentrated sulphuric acid was then added from the side of test tube. A pink coloration formed at the junction of two layers indicated presence of terpenes and the green colouration formed in upper layer showed presence of steroids.

\subsubsection{Test for saponins}

According to a method of Astuti,Sakinah, Andayani and Risch,(2011)[29], $0.5 \mathrm{~g}$ of extract was added to $5 \mathrm{ml}$ of distilled water in a test tube. The solution was shaken vigorously and observed for a stable persistent froth. The frothing was mixed with 3 drops of olive oil and shaken vigorously after which it was observed for the formation of an emulsion, which indicated the presence of saponins.

\subsection{Phytochemical analysis}

\section{Results}

Phytochemical analysis was carried out in a total of 50 plants, five each from 10 families. The families included Asteraceae (Table 1), Acanthaceae (Table 2), Araceae (Table 3), Apocynaceae (Table 4), Fabaceae(Table 5), Lamiaceae (Table 6), Poaceae (Table 7), Rutaceae (Table 8) and Malvaceae (Table 9). The families were randomly selected from the angiosperm group present in the University Botanic Garden of Maseno, Maseno University, Kenya.

Table 1: Phytochemicals present in leaves of five plants from Asteraceae family

Fr

\begin{tabular}{|l|c|c|c|c|c|c|}
\hline $\begin{array}{l}\text { Phytochemical } \\
\text { Asteraceae }\end{array}$ & Terpenes & Steroids & Flavonoids & Anthraquinones & Alkaloids & Saponins \\
\hline Tithonia diversifolia & - & + & & - & + & + \\
\hline Vernonia amygdalina & + & + & - & - & + & + \\
\hline Conyza bonariensis & + & + & - & - & + & + \\
\hline Bidens pilosa & - & + & - & - & - & + \\
\hline Spilanthes mauritiana & + & - & - & - & + & - \\
\hline \multicolumn{7}{|c|}{3} \\
\hline
\end{tabular}

Table 2: Phytochemicals present in leaves of five plants from Acanthaceae family

\begin{tabular}{|l|l|l|l|l|l|l|}
\hline $\begin{array}{l}\text { Phytoehemical } \\
\text { Acanthaceae }\end{array}$ & Terpenes & Steroids & Flavonoids & Anthraquinones & Alkaloids & Saponins \\
\hline Justicia flava & - & - & - & - & - & + \\
\hline Thunbergia alata & + & - & + & - & + & + \\
\hline Sanchezia speciosa & - & - & - & + & - & + \\
\hline Aphelandra squarosa & - & - & - & - & - & + \\
\hline Acanthus pubescens & + & - & + & & + & + \\
Fr
\end{tabular}


Table 3: Phytochemicals present in leaves of five plants from Araceae family

\begin{tabular}{|l|l|l|l|l|l|l|}
\hline $\begin{array}{l}\text { Phytochemical } \\
\text { Araceae }\end{array}$ & Terpenes & Steroids & Flavonoids & Anthraquinones & Alkaloids & Saponins \\
\hline Caladium bicolour & - & - & - & - & & + \\
\hline Colocasia esculenta & - & - & - & - & - & + \\
\hline Monstera deliciosa & - & - & - & - & + & + \\
\hline Dieffenbachia seguine & - & - & - & - & + & + \\
\hline Syngonium podophyllum & - & - & - & & + \\
\hline
\end{tabular}

Table 4: Phytochemicals present in leaves of five plants from Apocynaceae family

\begin{tabular}{|l|l|l|l|l|l|l|}
\hline $\begin{array}{l}\text { Phytochemical } \\
\text { Apocynaceae }\end{array}$ & Terpenes & Steroids & Flavonoids & Anthraquinones & Alkaloids & Saponins \\
\hline Tabernaemontana stapfiana & - & - & + & - & & + \\
\hline Mondia whitei & - & - & + & - & & + \\
\hline Plumeria rubra & - & + & - & + & + & + \\
\hline Thevetia peruviana & - & + & - & + & + \\
\hline Acokanthera schimperi & + & + & - & + & + \\
\hline
\end{tabular}

Table5: Phytochemicals present in leaves of five plants from Fabaceae family

\begin{tabular}{|l|l|l|l|l|l|l|l|}
\hline $\begin{array}{l}\text { Phytochemical } \\
\text { Fabaceae }\end{array}$ & Terpenes & Steroids & Flavonoids & Anthraquinones & Alkaloids & Saponins \\
\hline Crotalaria ochroleuca & - & + & + & - & & + & + \\
\hline Vigna unguilata & - & - & - & - & & + & + \\
\hline Erythrina abyssinica & + & - & - & - & + & + \\
\hline Sesbania sesban & - & - & + & + & + & + \\
\hline Phaseolus vulgaris & - & - & - & - & + \\
\hline
\end{tabular}

Table 6: Phytochemicals present in leaves of five plants from Lamiaceae family

\begin{tabular}{|c|c|c|c|c|c|c|}
\hline $\begin{array}{l}\text { Phytochemical } \\
\text { Lamiaceae }\end{array}$ & Terpenes & Steroids & Flavonoids & Anthraquinones & Alkaloids & Saponins \\
\hline Leonotis nepetifolia & _- & - & + & - & + & + \\
\hline Leucas martinicensis & _- & - & + & _- & + & + \\
\hline Hyptis pectinata & - & - & __ & - & + & - \\
\hline Plectranthus verticillatus & + & + & _ & _ & + & + \\
\hline Rosmarinus officinalis & + & - & _- & - & + & + \\
\hline
\end{tabular}

Table 7: Phytochemicals present in leaves of five plants from Poaceae family

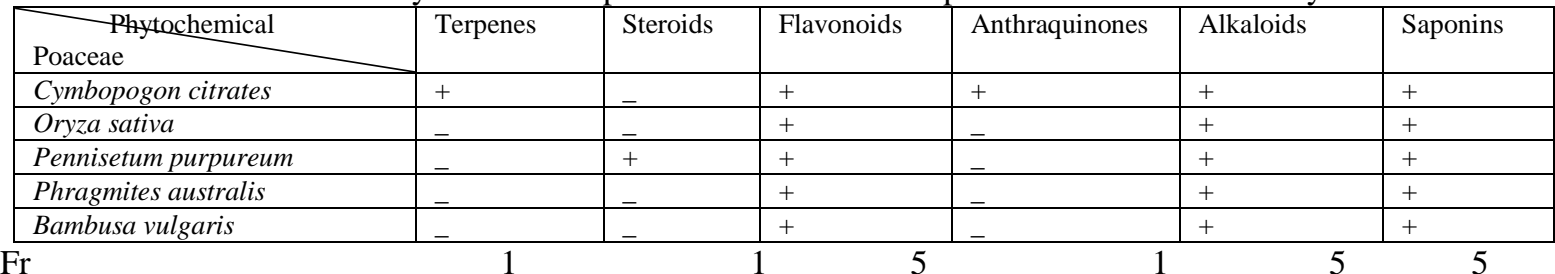

Table 8: Phytochemicals present in leaves of five plants from Rutaceae family

\begin{tabular}{|c|c|c|c|c|c|c|}
\hline $\begin{array}{l}\text { Phytochemical } \\
\text { Rutaceae }\end{array}$ & Terpenes & Steroids & Flavonoids & Anthraquinones & Alkaloids & Saponins \\
\hline Clausena anisata & - & _ & $\ldots$ & $\ldots$ & _ & + \\
\hline Fagaropsis angolensis & - & + & + & - & + & + \\
\hline Citrus limon & + & + & _ & _ & + & + \\
\hline Citrus sinensis & + & + & - & _- & + & + \\
\hline
\end{tabular}

Table 9: Phytochemicals present in leaves of five plants from Solanaceae family

\begin{tabular}{|c|c|c|c|c|c|c|}
\hline $\begin{array}{l}\text { Phytochemical } \\
\text { Solanaceae }\end{array}$ & Terpenes & Steroids & Flavonoids & Anthraquinones & Alkaloids & Saponins \\
\hline Datura stramonium & $=$ & $=$ & + & - & + & + \\
\hline Brugmansia candida & _ & _ & _ & _ & + & + \\
\hline Solanum incanum & - & - & + & _ & + & + \\
\hline Solanum scarbrum & - & + & + & + & + & + \\
\hline
\end{tabular}


Table 10: Phytochemicals present in leaves of five plants from Malvaceae family

\begin{tabular}{|c|c|c|c|c|c|c|}
\hline $\begin{array}{l}\text { Phytochemical } \\
\text { Malvaceae }\end{array}$ & Terpenes & Steroids & Flavonoids & Anthraquinones & Alkaloids & Saponins \\
\hline Hibiscus rosa-sinensis & _ & + & + & _ & + & + \\
\hline Sida cordifolia & $=$ & _ & - & _ & + & + \\
\hline Urena lobata ssp. lobata & + & 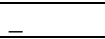 & + & _ & - & + \\
\hline Sida rhombifolia & _ & + & + & - & - & + \\
\hline Urena lobata ssp.sinuate & + & _ & + & _ & & + \\
\hline
\end{tabular}

Key: $\quad$ + Present; - Absent; Fr - Frequency of occurrence.

Total frequency of occurrence of the terpenes, steroids, flavonoids, anthraquinones, alkaloids and saponins was recorded at 16, 18, 22, 4, 40 and 48times in the families of study. 50 plants, five each belonging to ten families were selected and their ethanoic leaf extracts tested for the presence of six phytochemicals. From the table, it's evident that saponins are the most abundant phytochemicals among the plants whose leaf extracts were analyzed. They account for $32.43 \%$, followed by alkaloids $(27.03 \%)$ then flavonoids $(14.86 \%)$, steroids $(12.16 \%)$, terpenes $(10.81 \%)$ and anthraquinones $(2.70 \%)$ respectively.

Saponins were detected in all the plant leaves apart from the leaves of Hyptis pectinata and Spilanthes mauritiana. Saponins exhibit a unique property of formation of foams in aqueous solutions, cholesterol building properties, bitterness and haemolytic activity (Sodipo, Akiniyi and Ogunbamosu,2000[30]; Okwu, 2004[31]). Plants produce saponins to fight infection by parasites (Okello, 2007) [32] and probably this could explain why this phytochemical is common among these plants.

Alkaloids were detected in leaves of all the plants apart from 10 plants. These phytochemicals are normally abundant in plants and their absence in the 10 plants leaves can be explained in light of the fact that alkaloids are often restricted to specific organs within the plant among the angiosperms [32]. Many alkaloids have antibiotic properties suggesting defense against microbial infection [31].

Anthraquinones were only detected in four plants. Their rare occurrence could be due to environmental, ecological and even diurnal fluctuations depending on time of collection. The methodology employed could probably only detect them under high concentrations. Flavonoids were detected in 22 plants. These phytochemicals are potent water soluble antioxidants and free radical scavengers which prevent oxidative cell damage and have strong anticancer activity [31].

Terpenes and steroids were present in 16 and 18 plants respectively. Terpenes are a large and diverse class of organic compounds, produced by a variety of plants, particularly conifers. Steroids are derivatives of triterpenes squalene [33]. This probably explains why the leaf extraction of some plants tested positive for the presence of terpenes and steroids. In some plant extracts however, steroids were detected but not terpenes. This could be as a result of methodology employed. Terpenes are released by trees more actively in warmer weather [32].

Chi-square analysis at $\mathrm{P}<0.05$, reveals that there is a relationship between the phytochemical present in the plant and the plant family where the plant is grouped. Further analysis of the phytochemical data (Table 7.0) shows that certain plant families are closely related based on their phytochemical composition. The plant families Solanaceae and Rutaceae all have phytochemical composition mean of 60.0, indicating that the families are closely related. The close relationship between the Solanaceae and Rutaceae plant families is supported by Selvakumare, Gahloth, Tomar, SharmaandSharma,(2011)[34]in their "Molecular evolution of miraculin-like proteins study" which indicates that members of these two plant families contain these proteins. Many of them possess trypsin inhibitory activity, involved in plant defense.

Apocynaceae has phytochemical composition mean of 53.5, Asteraceae family has phytochemical composition mean of 50.3 whereas Malvaceae family has phytochemical composition mean of 50.2(Table 7). The three means do not significantly differ therefore indicating that the three plant families are closely related. The plant family Lamiaceae, Fabaceae and Acanthaceae have phytochemical composition mean of 46.8, 43.5 and 40.2(Table 7), respectively. The means of these three plant families also do not significantly differ, indicating that the three plant families are closely related. This close relationship between the Lamiaceae and Acanthaceae plant families is supported by Reddy,Rao, Reddy and Janardhana (2004)[35]. However, the two families differ from each other by the nature of their inflorescence, ovary as well as fruit of the plant species. Lastly there is the Araceae family which has a mean of 30.7. This mean significantly differs from all the other means, indicating that this family, based on its phytochemical composition, is not related to any of the nine plant families.

Fifty plants were screened and showed the presence of several secondary metabolites. Most showed presence of saponins, followed by alkaloids. This is in agreement with the qualitative phytochemical experiments done by [32] and [3] who found out that alkaloids were abundant in plants. However, more research need to be carried out to establish why saponins are abundant in the leaf extracts of the plants found in the 
UBGM. Bioassay studies needs to be carried out to establish the efficacy and potency of the phytochemical compounds and there possible utilisation at on large scale production. Further studies can establish many and different phytochemical compounds. Possibility of novel phytochemical compound is very high given the diversified evolutionary trees' nature, punctuated climate regime and varied plant responses to environmental factors and pressures.

Table 7. Composition of phytochemical compounds in selected plant families

\begin{tabular}{|c|c|c|c|c|c|c|c|}
\hline $\begin{array}{l}\text { Phytochemic } \\
\text { al } \\
\text { Compounds }\end{array}$ & \multirow[t]{2}{*}{$\begin{array}{l}\text { Alkaloid } \\
\text { s } \\
(\%)\end{array}$} & \multirow[t]{2}{*}{$\begin{array}{l}\text { Anthraquinon } \\
\text { es }(\%)\end{array}$} & \multirow[t]{2}{*}{$\begin{array}{l}\text { Flavonoi } \\
\text { ds } \\
(\%)\end{array}$} & \multirow[t]{2}{*}{$\begin{array}{l}\text { Saponin } \\
\text { s } \\
(\%)\end{array}$} & \multirow[t]{2}{*}{$\begin{array}{l}\text { Steroids } \\
(\%)\end{array}$} & \multirow[t]{2}{*}{$\begin{array}{l}\text { Terpene } \\
\mathrm{s} \\
(\%)\end{array}$} & \multirow[t]{2}{*}{$\begin{array}{l}\text { Plant } \\
\text { Familie } \\
\text { s Means }\end{array}$} \\
\hline $\begin{array}{ll}\text { Plant } \\
\text { Families }\end{array}$ & & & & & & & \\
\hline Acanthaceae & $40 \mathrm{~d}$ & $20 \mathrm{e}$ & $40 \mathrm{~d}$ & $100 \mathrm{a}$ & $1.0 \mathrm{f}$ & $40 \mathrm{~d}$ & 40.2 \\
\hline Apocynaceae & $100 \mathrm{a}$ & $1.0 \mathrm{f}$ & $40 \mathrm{~d}$ & $100 \mathrm{a}$ & $60 \mathrm{c}$ & $20 \mathrm{e}$ & 53.5 \\
\hline Araceae & $80 \mathrm{~b}$ & $1.0 \mathrm{f}$ & $1.0 \mathrm{f}$ & $100 \mathrm{a}$ & $1.0 \mathrm{f}$ & $1.0 \mathrm{f}$ & 30.7 \\
\hline Asteraceae & $80 \mathrm{~b}$ & $1.0 \mathrm{f}$ & $1.0 \mathrm{f}$ & $80 \mathrm{~b}$ & $80 \mathrm{~b}$ & $60 \mathrm{c}$ & 50.3 \\
\hline Fabaceae & $80 \mathrm{~b}$ & $1.0 \mathrm{f}$ & $40 \mathrm{~d}$ & $100 \mathrm{a}$ & $20 \mathrm{e}$ & $20 \mathrm{e}$ & 43.5 \\
\hline Lamiaceae & $100 \mathrm{a}$ & $1.0 \mathrm{f}$ & $40 \mathrm{~d}$ & $80 \mathrm{~b}$ & $20 \mathrm{e}$ & $40 \mathrm{~d}$ & 46.8 \\
\hline Malvaceae & $40 \mathrm{~d}$ & $1.0 \mathrm{f}$ & $80 \mathrm{~b}$ & $100 \mathrm{a}$ & $40 \mathrm{~d}$ & $40 \mathrm{~d}$ & 50.2 \\
\hline Poaceae & $100 a$ & $20 \mathrm{e}$ & $100 a$ & $100 \mathrm{a}$ & $20 \mathrm{e}$ & $20 \mathrm{e}$ & 60.0 \\
\hline Rutaceae & $80 \mathrm{~b}$ & $20 \mathrm{e}$ & $20 \mathrm{e}$ & $100 \mathrm{a}$ & $80 \mathrm{~b}$ & $60 \mathrm{c}$ & 60.0 \\
\hline Solanaceae & $100 \mathrm{a}$ & $20 \mathrm{e}$ & $80 \mathrm{~b}$ & $100 \mathrm{a}$ & $40 \mathrm{~d}$ & $20 \mathrm{e}$ & 60.0 \\
\hline $\begin{array}{l}\text { Phytochemic } \\
\text { al Means }\end{array}$ & 80.0 & 8.6 & 44.2 & 96.0 & 36.2 & 32.1 & 49.5 \\
\hline & \multicolumn{7}{|c|}{$\mathrm{LSD}_{(0.05)}=4.2 ;$ Standard Deviation $=2.57 ;$ Covariance $=5.20$} \\
\hline
\end{tabular}

Means followed by same letter do not significantly differ (Duncan's MRT, P = 0.05)

Table 8: Plant families and their phytochemical compounds occurrence as extracted from the laboratory

\begin{tabular}{|c|c|c|c|c|c|c|c|}
\hline & Terpenes & Steroids & Flavonoids & Anthraquinones & Alkaloids & Saponins & Total \\
\hline Asteraceae & 3 & 4 & 0 & 0 & 4 & 4 & 15 \\
\hline Acanthaceae & 2 & 0 & 2 & 1 & 2 & 5 & 12 \\
\hline Araceae & 0 & 0 & 0 & 0 & 4 & 5 & 9 \\
\hline Apocynaceae & 1 & 3 & 2 & 0 & 5 & 5 & 16 \\
\hline Fabaceae & 1 & 1 & 1 & 0 & 4 & 5 & 13 \\
\hline Lamiaceae & 2 & 1 & 2 & 0 & 5 & 4 & 13 \\
\hline Poaceae & 1 & 1 & 5 & 1 & 5 & 5 & 18 \\
\hline Rutaceae & 3 & 4 & 1 & 1 & 4 & 5 & 18 \\
\hline Solanaceae & 1 & 2 & 4 & 1 & 5 & 5 & 18 \\
\hline Malvaceae & 2 & 2 & 4 & 0 & 2 & 5 & 16 \\
\hline Total & 16 & 18 & 22 & 4 & 40 & 48 & 148 \\
\hline
\end{tabular}

Table 9:Chi-Square analysis of the data on the occurrence of phytochemical compounds and related plant families

\begin{tabular}{|l|l|l|l|l|l|l|l|}
\cline { 2 - 7 } \multicolumn{1}{c|}{} & Terpenes & Steroids & Flavonoids & Anthraquinones & Alkaloids & Saponins & Total \\
\hline Asteraceae & 1.225 & 2.689 & 2.2 & 0.4 & 0 & 0.133 \\
\hline Acanthaceae & 0.1 & 1.8 & 0.018 & 0.9 & 1 & 6.647 \\
\hline Araceae & 1.6 & 1.8 & 2.2 & 0.4 & 0 & 0.008 & 0.008 \\
\hline Apocynaceae & 0.225 & 0.8 & 0.018 & 0.4 & 0.25 & 0.826 \\
\hline Fabaceae & 0.225 & 0.356 & 0.018 & 0.4 & 0 & 0.008 & 0.008 \\
\hline Lamiaceae & 0.1 & 0.356 & 0.018 & 0.4 & 0 & 1.701 \\
\hline Poaceae & 0.225 & 0.356 & 3.564 & 0.9 & 0.25 & 0.133 & 0.008 \\
\hline Rutaceae & 1.225 & 2.689 & 0.655 & 0.9 & 0 & 5.007 & 0.008 \\
\hline Solanaceae & 0.225 & 0.022 & 1.473 & 0.9 & 0.25 & 5.477 \\
\hline Malvaceae & 0.1 & 0.022 & 1.473 & 0.4 & 0.25 & 0.008 & 0.008 \\
\hline Total & 5.25 & 10.89 & 11.637 & 6 & 2 & 2.878 \\
\hline
\end{tabular}

The occurrence of phytochemical compounds in related families of plants is shown in Table 8 . Flavonoids were absent in Araceae and Asteraceae whereas terpenes was not recorded in Araceae. Steroids were not recorded in Acanthaceae and Araceae; Anthraquinones were absent in Asteraceae and Malvaceae. Finally, Table 9 showed chi-square value of 36.107 less than value tabulated (61.656) at df (45) $\chi^{2} 0.050$ and hence not significant. Most of the plant species studied are conserved in the university botanic garden of Maseno (Sikolia and Seline, 2017) [36] and are representative of the rich equatorial Kakamega forest flora of western ecosystem in Kenya. 


\section{Conclusion}

Phytochemical analysis has been carried out on five plants each from ten selected plant families found in the UBGM. From the analysis, it is evident that the plants are rich in various phytochemicals and that these phytochemicals can sufficiently be used in their classification, especially at the confirmatory level. Most of the plants in the UBGM have been shown to possess phytochemical compounds-related to medicinal properties. More research on these plants need to be undertaken, especially on the plants that have not thoroughly been studied earlier. Further studies are recommended on such plants in order to isolate, identify, characterize and elucidate the structure of their bioactive compounds and consequently efficacy studies be carried out to establish the actual mode and mechanism of action. Thus, bioassay test and researches are advised. Further research is needed to carry out quantitative analysis on the phytochemicals found in plants of the same family, in order to verify if the yield of these phytochemicals can also be used as a basis for their classification.

\section{Acknowledgement}

The research team of the department of botany is highly appreciated including the technical staff support during the phytochemical compound analysis stage. Special gratitude goes to Seline Omondi for her effort during research work.

\section{References}

[1] BGCI,The Global network. http://www.bgci.org/global/, accessed on 21/06/2011, 2011a.

[2] Rinker,H.B.,The Weight of a Petal: The Value of Botanical Garden: .http://www.actionbioscience.org/biodiversity/rinker2.htm (Published by American Institute of Biological Sciences. 2002).

[3] Jeruto, P.,Ethno-Botanical Survey and Propagation of priority medicinal plants in Aldai region of Nandi south district,.M.Sc.Thesis, Maseno University, Kenya, 2008.

[4] Oldfield, S.,Tackling Invasive Species. BGjournal,8, 2011, 2.

[5] BGCI (2011b). The Global Trees Campaignhttp://www.bgci.org/ourwork/Rhododendron-Red-List, accessed on 21/06/2011, 2011b.

[6] Rukangira, E.,The African Herbal Industry: Constrains and Challenges; paper presentation at the natural products and cosmeceutical August 2001 conference. Erboristeria Domani, 2001.

[7] Swaminathan, M. S. and Kochhar, S. L., Plant and Society (London, Macmillan Publishers Limited, 1989).

[8] Nyunja, A. R. O., Onyango, J. C.and Beck, E.,The Kakamega forest medicinal plant resources and their utilization by adjacent Luhya Community. International Journal of Tropical medicine, 4, 2009, 82-90.

[9] Shakeri, A., Hazeri, N., Vlizadeh, J., Ghasemi, A. and Tavallaei, F. Z.,Phytochemical screening, antimicrobial and antioxidant activities of Anabasis aphylla L. extracts. Kragujevac J. Sci.,34,2012, 71-78.

[10] Nonita, P. P., and Mylene, M. U., Antioxidant and cytotoxic activities and phytochemical screening of four Philippine medicinal plants. Journal of Medicinal Plant Research, 4, 2010,407-414.

[11] Rahul, J., An Ethnobotanical study of medicinal plants in Taindol village, District Jhansis, Region of Bundlelhand, Uttar Pradesh, India. Journal of Medicinal Plants Studies, 1(5), 2013, 59-71.

[12] Ekeanyanwu, C.R., Traditional medicine in Nigeria: Current status and the future. Research Journal of Pharmacology, 5(6): 90-94.

[13] Wadood A, Ghufran M, Jamal SB, Naeem M, Khan, A.,Ghaffar, R. and Asnad, Phytochemical analysis of Medicinal plants occurring in Local Area of Mardan. Biochem Anal Biochem, 2(4), 2013, 1-4.

[14] Nyunja, A. R. O., Diversity of medicinal plants of Kakamega forest, Kenya: A taxonomic and pharmacological approach. A PhD. Thesis, Maseno University, Kenya, 2007.

[15] Eldin, S. and Dunford, A.,Herbal Medicine in Primary Healthcare (Butterwort-Heinemann, Oxford, 1999).

[16] Cammack, R., Teresa, A., Campbell, P., Howard, P., Smith, T., Stirling, J. and Vella, F., Oxford Dictionary of Biochemistry and Molecular Biology ( $3^{\text {rd }}$ Ed.)(Oxford University Press, 2006).

[17] Mutta, D.,Ethno-botanical study of medicinal nutritional species of Kajiado district in Kenya in: Kwaje, S. L. and Mwaura, F. B. (Eds),Proceedings of the first international workshop on capacity building in forestry research in Africa, African Academy of Sciences, Nairobi,1994.

[18] Githinji, C. W.,Ethnobotanical and Chemotaxonomic study of some Kenyan medicinal Labiatae species. M.Sc. Thesis, University of Nairobi, Nairobi, 1990.

[19] Onyango, M. A. O. and Onyango, J. C.,Conservation and seed production of African Leafy vegetables at Maseno University botanic garden, Kenya. African Crop Science Conference Proceedings, Vol. 7, 2005, 1201-1204.

[20] Omino, E. A.,A Study of Apocynaceae species used in traditional medicine in Kenya,M.Sc. Thesis, University of Nairobi, Kenya, 1990 .

[21] Noad, T. and Birnie, A., Trees of Kenya (Kenya, Nairobi, General printers Ltd, 1992).

[22] Agnew, A. D. Q and Agnew, S., Upland Kenya Wild Flowers. A Flora of the Ferns and Herbaceous Flowering Plants of Upland Kenya ( $2^{\text {nd }}$ Edition) (Kenya, Nairobi: East African Natural History, 1994).

[23] Olembo,N, Fedha, S.S. and Ngaira, E., Medicinal and Agricultural Plants of Ikolomani Division Kakamega district. (Kenya, Nairobi: Signal press Ltd, 1995).

[24] Kokwaro, J. O.,Luo-English Botanical Dictionary. (Nairobi, East African Publishing House, 1972).

[25] Kokwaro, J. O.,Flowering Plant Families of East Africa. An Introduction to Plant Taxonomy (Kenya, Nairobi: East African Educational Publishers, 1994).

[26] Stace, A. C., Taxonomy and Biosystematics $\left(2^{\text {nd }}\right.$ Ed). (London: Oxford University Press, 1993).

[27] George, N. J., Ikot, A. N. and Obi-Egbedi, N. O.,Phytochemical and Antimicrobial Properties of Leaves of Alchonea cordifolia.CODEN ECJHAO E-Journal of Chemistry, 7, 2010,1071-1079.

[28] Kumar, G.G. and V. Gali, V., Phytochemical screening of Abutilon muticum(Del. ex DC.) and CelosiaargenteaLinn. Int. J. Pharma Bio. Sci., 2,201, 463-467.

[29] Astuti, S. M., Sakinah, M., Andayani, R. and Risch, A.,Determination of Saponin Compound from Anredera cordifolia(Ten) Steenis Plant (Binahong) to Potential Treatment for Several Diseases.Journal of Agricultural Science, 3, 2011, $224-232$. 
[30] Sodipo, O. A., Akiniyi, J. A. and Ogunbamosu, J. U.,Studies on certain characteristics of extracts of bark of Pansinystalia macruceras(K. schemp) Pierre Exbeille. Global J. Pure Appl. Sci.,6, 2000,83-87.

[31] Okwu, D. E., Phytochemicals and vitamin content of indigenous spices of south eastern Nigeria. J. Sustain. Agric. Environ., 6, 2004,140-147.

[32] Okello, S. V., Ethno-botanical survey and phytochemical analysis of medicinal plants in Kopsiro division of Mt. Elgon district, Kenya. M.Sc. Thesis, Maseno University, Kenya, 2007.

[33] Wikipedia Encyclopedia,Terpenes.http://en.wikipedia.org/wiki/Terpenes. Accessed on 12/07/2012, 2012.

[34] Selvakumar, P., Gahloth, D., Tomar, P. P., Sharma, N. andSharma A. K., Molecular evolution of miraculin-like proteins in soybeanKunitz super-family. J. Mol. Evol., 73, 2011, 369-79.

[35] Reddy, S. M., Rao, M. M., Reddy, A. S. and Janardhana S. C.,University Botany 3(New Delhi, New Age International Publishers Ltd, 2004).

[36] Sikolia, S.F. and Omondi, S., Checklist of plants in the University Botanic Garden of Maseno and their significance to the society. Journal of Pharmacy and Biological Sciences (Press), 2017.

Stephen F. Sikolia. "Phytochemical Analysis of Some Selected Plants and Families in the University Botanic Garden Of Maseno, Kenya." IOSR Journal of Pharmacy and Biological Sciences (IOSR-JPBS) 12.4 (2017): 31-38. 